\title{
Military Enlisted Tactical Operations and Air/Weapons Specialists and Crew Members
}

National Cancer Institute

\section{Source}

National Cancer Institute. Military Enlisted Tactical Operations and Air/Weapons

Specialists and Crew Members. NCI Thesaurus. Code C122485.

The group of professions that include air crew members, aircraft launch and recovery specialists, armored assault vehicle crew members, artillery and missile crew members, command and control center specialists, infantry members, radar and sonar technicians, and special forces members. 